\title{
ブログ学習活動における教師フィードバックの役割 \\ 一上級日本語学習者の視点から一 \\ The effect of blog activities and the role of teacher feedback: \\ From the perspective of advanced Japanese learners
}

\section{連 沁怡 \\ 香港理エ大学}

\section{要旨}

海外では日本語を使う環境が教室内に限定されており、日本語の使用機会を 増やすことが言語教育の課題の一つである。学習者は主体的にインターネットを ベースにした多彩な言語活動を行っているが、そこで教師がどのような立場で いかなる役割を果たすべきか更なる研究が必要とされている。本稿は 2017 年に ある上級日本語課程で行われたブログ学習活動を対象とし、学習者の視点から 活動効果を分析した。ブログ学習活動後のインタビュー調査から、教師フィード バックの方法が学習意欲、言語表現、活動参与などの面に影響を与えていること が明らかになった。ブログ学習活動のデザインと実施、そして自律的学習の角度 から、日本語教育におけるブログ使用の可能性を示唆する。

キーワード :

日本語教育、ブログ学習活動、教師フィードバック 


\section{ブログ学習活動における教師フィードバックの役割 \\ 一上級日本語学習者の視点から一}

\section{連 沁怡 \\ 香港理エ大学}

\section{1.はじめに}

Warschauer \& Healay がコンピュータ支援言語学習（以下は CALL）の発展を、

(1) 行動主義的 CALL (behavioristic CALL、1950s 1970s)、（2 ）Communicative CALL (1980s 1990s)、（ 3 ） Integrative CALL (1990s 2000s)、と、いくつかの段階 に分けた(1998：57-58)。これらの段階は構造主義や行動主義から認知言語学、 そして言語社会化論などへの学習理論の発展を反映している。コンピュータ技術 の発展につれて、「Mobile-Assisted Language Learning」(Chinnery 2006、Gikas \& Grant 2013)、「Social Media Language Teaching Study」(McLoughlin ほか, 2010)、

「Language Learning Apps」(Godwin-Jones, 2011)などのように、通信技術が言語 教育での運用が広がり、さらに異文化間交流も言語学習の視野に取り入れられて きて、Thorne がそれらの変容を言語教育活動の「Intercultural Turn」(2010:139) と 提唱した。従来から Ellis はタスクを解決するうちに、学生は明示的な宣言的知識 (declarative knowledge)を消化し、暗示的な手続き的知識(procedural knowledge)に 移行する第二言語習得の促進のためには、言語を使ってある目的を遂行する タスクを中心とするコミュニケーション活動を使用することを主張していた (1993:109)。言語教育現場に異文化交流と社会参与を取り入れることは次第に重視 されてき、実現できるようになったと言える。

インターネットでは目標言語によるコミュニケーションは現実より比較的に 容易にでき、学生がいろんなツールに頼って（検索エンジンや辞書）失敗を恐れず 目標言語を使う環境が作られている。したがって、インターネットを活用した さまざまな教育実践が行われてきた。日本語教育の現場もデジタル機械の普及と 情報電子化の風潮につれ、パソコンやインターネットを活用した作文指導が増える 傾向にある。例えば、鎌田と山崎(2002)は掲示板における参加者間のやりとりが 日本語学習に与える影響と作文の質と量に対して考察した。生田(2010) は ライティングプロジェクトを含むCALL 英語教育を実施し、プロジェクトを作成 するにあたり、学習者は資料収集、英語の読み込み、情報の整理など、目標言語 での作業が要求されていた。その結果、語彙量リーディング能力の伸び率がより 高くて、CALL 環境でよりよい学習効果が得られることが判明した。

その中で注目したいのはブログ活動である。ブログ学習活動は「無料のブログ ツールが手軽に利用できる」ことと読者意識で書き手のモチベーションが高まる ことが利点として教育現場で幅広く利用、近年数多く報告されている（深田 


\section{ブログ学習活動における教師フィードバックの役割}

2014:16, Bloch 2007, 佐藤・深井・中澤 2011, Sun 2009）。文化交流に重き を置くブログ学習活動も少なくない。高宮はアメリカ大学生に授業のトピックを もとにブログを作成させ、協力してくれる日本人学生が定期的に書き込むコメント を教室で生かす実践をまとめ、文化理解をめざすブログ学習活動の実態を紹介 した(2011:161)。吉嶺加奈子(2014)による日本語学習者が展開した新聞部の活動に 関する報告では、学生が新聞の編集過程で直面した課題が説明され、活動を通して 「日本語能力の総合的な向上」と「メディアリテラシーの強化」という改善が 見える一方、読み手の希望と書き手の作文意罒に見られる乘離、また執筆 モチベーションの維持などの課題が取り上げられた。フィードバックのやり方に ついて、佐藤(2010)はアメリカで初級日本語学習者がブログ記事を軸に読み手と の交流を増やすことを目標とするブログ学習活動支援を実施し、言語の「正しさ」 にフィードバックをあえて行わなかったが、事後インタビューで学習者が適切さ に対する関心を判明し、今後それについて支援する必要を見出した。

フィードバックについては、多くの研究がなされている。Fathman \& Whallrey (1990)は、「内容、言語形式それぞれについて訂正やコメントを受けると、書き 直しのとき内容面でも言語形式でも向上がみられる」としており、言語形式の 向上の可能性を示唆している。Yoshida が 2008 年と 2009 年での観察では、教師が 学習者がエラーに対する認識を推測した上フィードバックを調整することが判明 した(2010:294)。

日本語教育におけるブログ学習活動については様々な観点から研究が進められ ているが、本稿で扱う、教師フィードバックの視点からブログ学習活動を分析 するものはまだ少ない。特に中国語母語話者の日本語ブログ学習活動に関する 研究は日本語教育におけるメリット（潘 2014）と実行可能性（严 2010）に止まり、 ケーススダディからフィードバック策略に関する研究はまだ足りないといえる だろう。

\section{2.上級クラスのブログ学習活動}

\section{1 上級クラスのブログ学習活動の概要}

今回のブログ学習活動では、および 10 名以上の上級日本語学習者が指導者から Wordpress.com でブログを開設し、「新聞やテレビ報道記事を資料にもとづいて、 私見を客観的に述べた内容で」、2 回のポストが 400 字以内、3 回目が 2000 字以内 に論考を作成するという指示を受けた。過去の学生のブログは参考例として、 リンクがアセスメント詳細に提供されていた。 
尚、このクラスは修士レベルの授業の一部であるため、「日本語言語能力」の 向上以外に、「メディアリテラシー」や「アカデミックライティング」の能力を 高めることも学習目的に含まれている。それ故、評価基準では「文章の正確さ」 以外、「文章構成」、「タイトルと導入部分の効果性」、「内容についての専門 性の高さ」、「情報の信憑性」なども求められる。ニュースの構造分析は普段の 授業で教われている。

以下は第一回のブログを作成するにあたり学習者 S5 と教師のメールやり取り から抽出したプロセスを例として、ブログ学習活動の流れを概観してみよう。

1、学習者 S5 は「食品口ス」に関寸るニュースに関心を持ち、それをテーマ にしたいというメールにニュースのリンクを貼り、先生の了承を求める。

2、教師はテーマを「おもしろいテーマだと思います」と肯定を示し、草稿を 作成しようと促す。また文章を書く場合の注意点、「読者の興味をどう すればそそれるのか」と学生の読者意識を喚起し、さらに参考資料の引用 の仕方についても提示した。

3、教師は学生全員にブログ記事の草稿の提出のフォローアップメールを 送り、評価基準表に注意を促し、締め切りまでの添削活動の回数が最終 評価に影響を与えることを強調した。

4、学習者 S5 は 1 回目の草稿を送り、教師からコメントをもらい、それを 参考に訂正した。文章の構造に関するコメントが大半だった。

5 、学習者 S5 は 2 回目の草稿を送り、教師からコメントをもらい、それを 参考に訂正した。2 回目のコメントでは内容面に関するもの以外、日本語 の正確さも重視され始めた。

6 、学習者 S5 は 3 回目の草稿を送り、教師からコメントをもらい、訂正した 最終版をアップロードする指示をもらった。ブログに載せることは課題を 完成したと見なされる。

このように、実際のブログ学習活動では、各学生がまずトピックを選択し、 教師から方向性に関する指示を貪った上、草稿を書き、メールで教師に送付し、 教師のコメントにもとづいて草稿を書き直す。草稿の提出時間により個人差が あるが、一人一週間から二週間をわたる添削活動の後、自分の記事をブログに パブリッシュする。添削活動に関する教師とのやりとりの 90 パーセント以上は メールで行い、教室内ではトピックに関するやりとりも少数出てきた。教師は 主にトピック選定からブログへ投稿するまでのプロセスを支援する役割を果たし ていた。 


\section{2 上級クラスのブログ学習活動の課題}

\section{2.1 学習者のブログ学習活動への態度と教師フィードバック}

コース終了後、学習者の 6 人には簡単な調査を実施した。調査問題は以下の 通り：

(1).ブログ学習活動を書く時、先生以外の読み手を予想していますか。

(2).ブログに掲載されているポストにはコメントが入っていますか。

(3).ブログ学習活動は授業終了後も継続していますか。

調査した結果、質問(1)と(2)に対して全員「予想していない」、「コメントが入って いない」と回答し、質問(3には学習者 S2 が「アカウントを削除した」と回答した 以外、残りの 5 人が「放置したまま」と答えた。インタビューの中、学習者 S6 が「課題を発表する場所を変えたと感じただけ」と述べ、学習者 S1 がトピック の選定段階で「アニメ」をテーマにしたいと表明したが、教師から「新聞価值が あんまりない」と否定的なフィードバックをうけた末、ブログ学習活動に拒否感 を抱き始め、ブログ学習活動を低く評価したことがインタビューからみえてきた。

佐藤(2010)によると、読み手の存在が学習者にブログ学習活動を継続させ、 読み手を意識させながら文章を作成するという点において重要な役割を果たして いる（2010:55）。今回のブログ学習活動のアセスメント基準では同じく、「読者 を魅了するような文章の組み合わせのこと」が推奨され、読者意識を持ちながら ブログ学習活動に参加することは目的の一つと考設置した。しかしながら、学習 者の回答から見ると、彼らにとって今回のブログ学習活動はただの課題に過ぎ ない。教師が喚起しようとする「読者意識」が結局学習者にとっては薄かった ことがわかった。加えて、吉嶺加奈子(2014)では読み手とコメント数などの外部 的要因が学習者のモチベーションに深く影響していると論じている。現に学習者 S5 はアクセス数を増やしたいと思い、自らブログ学習活動のリンクを Facebook に乗せた経験があることから、読み手が作り手（学習者）にとって重要な存在で あり、ブログを書く原動力の一つであると考えられる。

一方、教師から学習者 S5 ヘのメールでは、「(草稿 3 を訂正したもの)を使えば、 最終稿として Wordpress にアップロードすることができるはずです。アップ ロードができたら，リンクを送ってください。それで提出とみなします。」と、 ブログ学習活動をコミュニケーション活動より、課題として考えているという 教師の立場を示し、それによって学習者が教室活動のイメージが強化されたの ではないかと予測できる。ブログ学習活動では先生に見せるために文章を書く ようになる受動的な態度がある程度反映されていると言えるだろう。 


\section{2.2 ブログ学習活動のフォーカスと教師フィードバック}

今回のブログ学習活動における教師フィードバックはメール以外、添付された ワープロファイル内のコメント機能と変更履歴機能で実現されていた。教師 フィーとバックは校閲機能をオンにした状態で（1）そのまま本文を修正する もの、（2）意見をそのまま本文に挿入するもの、そして（3）内容を選択して 吹き出しでコメントするもの三つに分けられる。フィードバック（1）は主に 表記、文法、書式、加筆、書き換えなどの「表面的な推敲」(Surface Changes) (Faigley \&Witte, 1981:402)であり、（2）と（3）は文章構成や情報の根拠、記事内容に ついての「内容面的な推敲」(Meaning Changes)が多い。

学習者 S6 の添削プロセスを見てみましょう。1 回目では総計 51 箇所の添削を 貪い、その中 15 箇所が「助詞」、「助詞が抜けている」のように、文法・語彙 面に関するものである。それに加えて、「単に過去の事実とするより，今も意見 が変わらないという意味で，現在形にすると良い。」と、話し手の立場が表現へ の影響を説明するものもある。2 回目では「このブログ記事の目的（書く目的。 読者にとっては，これを読む目的，読んで学べること）を冒頭の段落で明示する。 目的がないので，インパクトが弱くなっている。」と、構造的な弱さを指摘して いる。学習者がそれに従って、3 回目で提出した草稿では、「このブログでは、 〜について考えてみたい。」のように教師が入れて欲しい内容を加えた。3回目 の記事では、少し語彙の修正を入れただけだ。

学習者 S5 と教師のメールのやりとりから、教師フィードバックのフォーム も見られる。3 回目の添削メールでは「これで内容的にはまとまるはずです。 それができたら，あとは日本語を完璧にしてできあがりです。」と書いている。

「内容面十表面」から「表面」への添削フォームでは、表面的な推敲が内容的な 推敲ほど重要ではないという教師の意図が示されていて、学習事項と評価基準と も一致している。

つまり、教師にあたえられる添削時間とコースの目標がフィードバックの フォームとフォーカスに影響があると判明した。

\section{2.3 教師フィードバックが効果的なのか}

教師フィードバックは学習者自身の言語使用や言語習得に対する一つの情報源 であり、文法、文章構成、内容に関する指摘など、どのような側面からの指摘で あっても、学習者には有益のほうであると言われている(佐藤 2010)。内藤と中野 (2014)の研究では、中級レベルの作文クラスでの「どこが不適切なのかについて コメントがないと直しにくい」という学生からの反響が報告され、また具体的な 指摘によって第二稿で適切な修正がなされた一方、抽象的な指摘に対して放置さ れることが多いと指摘された。というのは、明示的なフィードバックがより効果 的であると多くの研究が主張している。 


\section{ブログ学習活動における教師フィードバックの役割 \\ 一上級日本語学習者の視点から一}

以下は教師が学習者 S5 が人工授精に関するニュースに基づき作成したコラム に対して理解できない場合、出したコメントを例として、内容面的な推敲の種類 について説明する（下線部分が噴出しコメント欄がハイパーリンクする部分）。

(1).ただ「理解できない」という気持ちを示す。例えば、教師が「朝日新聞に よると、ネットで精子の提供者と個人的なやりとりをして人工授精ができ、 さらに妊娠の確率を上げるための性行為をするところもあるらしい。」と いう文章について、「これは意味がわからない。」と吹き出しで評した。 学習者 S6 がインタビューで同様なコメントをもらったと述べた。

(2). 具体的にどこが理解できない、なにを修正すべきかを指摘する。上述した 学習者 S6 と同じように「ブログを書く目的が書かれていない」という問題 点について、教師が学習者 S5 の第一稿の始まりに「冒頭で，ブログの目 的（読者が読む理由, 読んで何がわかるのか）を明記する必要がある。読 んでいて，何を読んでいるのか，わからない。」とコメントをそのまま挿 入した。

(3). 学習者の意図を推測する。「不妊治療における精子提供はまだしも、銀行 からお金をおろすような仕方で利用する精子バンクの監用は、子育ての不 謹慎につながる可能性があるし、性交渉に伴う金銭のやりとりを法律違反 としてみるべきかどうか、未だに規則が整っていない。」という文章の中 で、教師が「不謹慎」について「いいたいことがわからない。子育ての不 謹慎とは普通いわない。子育てができないこと?」と学習者 S5 の表現意図 を測ろうとする。

Gardner \& MacIntyre (1985)では「言語姿勢」、「動機」、「不安」、「自信」、 「性格」、「学習スタイル」など学習者があらゆる状況への反応を情緒的要因 (Affective Variables)として取り上げ、この要因は学習状況と過程において重要は 役割を果たしていると考えられる。「理解できない」のようなコメントに対し、 学習者 S5 と学習者 S6 が「それを読んですごく悲しかった」とインタビューで表 明し、学習者に消極的な影響を与えたと判明した。ところで、2 のような具体的 な指示に対して、第二稿では学習者 S5 が要領を得て「タイトルと導入部分が効 果的か」という評価基準に参照して、冒頭でブログの目的を明記するようになっ た。他にも、「指導者がネガティブな評価を出すとき、より具体的な指導が欲し い」という学生の声もあった。 
どうやら「どのような側面からの指摘であっても、学習者には有益のほうである」 ということは絶対的ではないのだろう。Aljaafreh, A. L., と Lantolf, J. P. によると、 明示的フィードバック (explicit feedback)と暗示的フィードバック (implicit feedback)が言語的発展と関係するが、学習者と言語知識の達者との交渉が欠かさ ない。ある場合では、明示的フィードバックのほうが学習者から活発な反応を 引き出す。（1994:466-467）ブログ活動の場合、学生の即時反応をもらえない ため、明示的フィードバックの方が学生の学習意欲を喚起できて、効果的である と思われる。

\section{3. まとめと今後の展望}

\section{1 まとめ}

本研究の結果から、ブログ学習活動を実施するとき学習者の学習意識と教師 フィードバックの形と内容はブログ学習活動にもたらす影響が示された。ブログ 学習活動は教室の延長に位置付けられたからといって、学生の主体性を引き出さ ないと意味が薄くなってしまう恐れがある。新聞評論をモデルとするブログ学習 活動のテーマの選別やポストの作成段階の指導にあたっては、学習者の受動的な 立場を主動的な「記者」への立場転換を促し、新聞価值を考慮させる、そして 教師から「押し付けられた」ブログ学習活動を自発的に持続することとブログ学習 活動を軸に日本人との交流を深めることを目指寸異文化語学教育も視野に入れる 必要があるといえるだろう。

更に、教師フィードバックでは学習者に語彙を修正させたいか、文章の構成を 練り直させるか、明確なアドバイスを出すことで学習者が誤りを意識する効果が 証明されたが、学習者の日本語能力を向上させたいという善意からうまれた アドバイスによる学生の自尊心に与える劦威、および学習意欲にもたらす影響が 調査とインタビューから明示された。教師が作文にコメントする際、学習者要因 と個人差に適して、積極的、消極的なフィードバックを使い分けることと、教師 と学生の対面による議論でより効果的な作文指導が実現できるだろう。

\section{2 今後の展望}

ブログ学習活動では豊富な言語運用ができ、比較的に完成度の高いディス コースを書き込むことができる一方、ソーシャルメディアで可能となる他者との 交流が割と頻繁ではない欠点があるといえるだろう。これまで日本語教育現場で 行われたブログ学習活動でも、日本人学生にコメントしてくれるようにアレンジ したケースが多い。イントラクションがすくないことで、第二言語運用の頻度と 母語者の生の言語使用の規範に触れるチャンスも低下寸る恐れがあり、学習者が ブログ記事を書き続けるモチベーションを維持にくくなる。 


\section{ブログ学習活動における教師フィードバックの役割}

一上級日本語学習者の視点から一

言語教育におけるブログ学習活動をよりよく利用するために、まずは、自立的 な学習者を育成するという観点から、ブログ学習活動を学習者の生涯学習の一環 として利用させるため、自主的な推敲を行う能力を培うことの重要性に注目して ほしい。本研究では、調査対象となる 7 人の生徒中、誰一人もブログを継続して いないという状況が明らかである。それについて、「めんどくさがっている」、

「書いても読む人、コメントしてくる人がない」、「ブログをやるとしても、新聞を テーマにしたくない」などの心境は学習者へのインタビューから明らかになった けど、「書いてもこれが正しいかどうかはわからない」という理由から自主修正 能力の育成は今後の日本語教育、特に作文教育に取り込む必要性があると言える だろう。

次に、学習者のモチベーションの維持を実現するためには、ピア・レスポンス (peer response)の導入を検討する価值がある。Ellis は「豊富なコミュニケーション 活動の中で、学習者に言語の形に気付かせ、その明白な知識を学習させるのが、 効果的である」と、教室イントラクションが学習効果の向上に繋がると述べて いる。ピア・レスポンスとは、「学習者が少人数のグループでお互いの作文に ついて話し合う学習活動である」（広瀬 2004：76）。広瀬はピア・レスポンス による推敲後の作文に与えた効果と学習者同士の批判的な読みへの促進がすでに 検証されたが、教師フィードバックとの組み合わせも重視する必要があると述べて いる。日本語母語話者が参加することによる支援が難しい場合、ピア・レスポンス が交流の不足を補う役割を果たすことが期待できる。

最後に、社会参加の一環になせるようなブログ学習活動も視野に入れて学習 デザインの改善を目指したい。ブログ学習活動によって起こる問題点を教室内で 共有したり、また、「コミュニディー」への参入を目指す真のコミュニケーション 活動であるが行われている朝日新聞フォーラム、Lang-8 などのような学習者同士 が母語を教えあう「作文相互添削型 SNS」（小松 2011）省教育現場に導入し たり、学習者に「学習者以外の立場」（佐藤他 2011）を取り入れさせたりする ことで、新しい学びを生み出す可能性が出て来ると思う。 


\section{参考文献}

小松祐子 (2011)「ソーシャルメディアと外国語学習・教育ーフランス語の新しい学びのため に一」『関西フランス語教育研究会 2011』,76-80

小林ミナ (2014)「書評論文 本田弘之・岩田一成・義永美央子・渡部倫子著『日本語教育学

の歩き方 初学者のための研究ガイド』」第二言語としての日本語の習得研究』17 卷, 59-79 内藤真理子・中野陽 (2014)「作文の自己修正を促すための教師フィードバックとピア・ レスポンスー自律的な書き手となることを目指した中級日本語作文授業の実践報告一」

『日本語教育方法研究会誌』21 卷, 1 号, 100-101

広瀬和佳子 (2004)「ピア・レスポンスは推敲作文にどう反映されるか--マレーシア人中級

日本語学習者の場合」『第二言語としての日本語の習得研究』卷 7,60-79

吉嶺加奈子 (2014)「日本語能力向上につながる部活動一『カセ日新聞』の一年間」『言語教育 実践 イマ×ココ』号 2, 22-23

佐藤慎司・深井美由紀・中澤一亮 (2011)「文化概念を取り込んだ活動：ブログ・プロジェクト

実践概要」『社会参加をめざす日本語教育：社会に関わる、つながる、働きかける』75-102, ひつじ書房出版

畑佐由紀子 (2016) 「書評論文 大関浩美編著『フィードバック研究への招待：第二言語習得

とフィードバック』」『第二言語としての日本語の習得研究』卷 19, 29-41

真嶋潤子 (2005)「学習者の個人差と第二言語習得--「学習スタイル」を中心に」『第二言語 としての日本語の習得研究』8 卷, 115-134

深田淳 (2014)「日本語教育におけるテクノロジー」『アメリカにおける日本語教育の過去・

現在・未来』1-25, AATJ.<https://www.aatj.org/resources/publications/book/Technology_Fukada.pdf> (2017 年 7 月 25 日)

鎌田倫子・山崎けい子 (2002)「電子掲示板による日本語教育の可能性」『日本語教育方法研究 会誌』9 卷, 2 号, 24-25

生田祐子 (2001) 「第 2 言語習得と C A L L 環境」『文教大学付属教育研究所紀要特集 大学 教育の情報化』10 号, 45-55

高宮優実 (2011) 「アメリカ大学における日本語教育」遠藤織枝編『日本語教育を学ぶ：その 歴史から現場まで』161, 三修社出版

佐藤梓 (2010) 「初級日本語学習者のブログ記事に対するフィードバック」『北海道大学 大学院国際広報メディア・観光学院院生論集』，6, 53-64

大学英語呚育学会 (2000) 『SLA 研究と外国語敎育：文献紹介』(第 1 版. ed.). リーベル出版 潘红艳. (2014). 博客在日语教学中的应用探究. 科技资讯, (34), 190.

严受知. (2010). 日语教学中应用博客可行性分析. 浙江树人大学学报：自然科学版, (01), 49-52. 陈向东, \& 王兴辉. (2003). 博客文化与现代教育技术. 电化教育研究, (3), 17-21.

Aljaafreh, A. L., \& Lantolf, J. P. (1994). Negative feedback as regulation and second language learning in the zone of proximal development. The Modern Language Journal, 78(4), 465-483.

Ashwell, T. (2000). Patterns of Teacher Response to Student Writing in a Multiple-Draft Composition Classroom: Is Content Feedback Followed by Form Feedback the Best Method? Journal of Second Language Writing, 9(3), 227-257.

Bakar, N. A., \& Latif, H. (2010). ESL Students feedback on the use of blogs for language learning. 3 : Language, Linguistics, Literature ${ }^{\circledR}, 16(1)$, Retrieved from

$<$ http://ejournals.ukm.my/3l/article/view/1008> 


\section{ブログ学習活動における教師フィードバックの役割 \\ 一上級日本語学習者の視点から一}

Bloch, J. (2007) Abdullah's Blogging: a Generation 1.5 Student Enters the Blogsphere. Language Learning \& Technology, 11(2), 128-141.

Chinnery, George M., 2006. Going to the MALL: Mobile Assisted Language Learning. Language Learning \& Technology, 10(1), pp.9-16.

Faigley, L., \& Witte, S. (1981). Analyzing Revision. College Composition and Communication, 32(4), 400-414.

Fathman, A., \& Whalley, E. (1990). Teacher response to student writing: Focus on form versus content. Second language writing: Research insights for the classroom, 9, 178-190.

Gardner, R. C. \& MacIntyre, P. D. (1993). A student's contributions to second language learning. Part II: Affective variables. Language Teaching, 26, 1-11.

Godwin-Jones, Robert. (2011). Mobile apps for language learning. Language, Learning \& Technology, 15(2), 2-11.

Gikas, \& Grant. (2013). Mobile Computing Devices in Higher Education: Student Perspectives on Learning with Cellphones, Smartphones \& Social Media. The Internet and Higher Education. 19, $18-26$.

McLoughlin, Catherine, \& Lee, Mark J. W. (2010). Personalised and Self Regulated Learning in the Web 2.0 Era: International Exemplars of Innovative Pedagogy Using Social Software. Australasian Journal of Educational Technology, 26(1), 28-43.

Sun, Y.C. (2009). Voice Blog: An Exploratory Study of Language Learning. Language Learning \& Technology, 13(2), 88-103.

Thorne, S. L. (2010). The 'Intercultural Turn' and Language Learning in the Crucible of New Media. In F. Helm \& S. Guth (eds.), Telecollaboration 2.0 for Language and Intercultural Learning. Bern: Peter Lang. 139-164.

Warschauer, M., \& Healey, D. (1998). Computers and language learning: An overview. Language Teaching, 31(2), 57-71.

Yoshida, Reiko. (2010). How Do Teachers and Learners Perceive Corrective Feedback in the Japanese Language Classroom? Modern Language Journal, 94(2), 293-314. 